\title{
THE HYPERGLYCAEMIC ACTION OF SODIUM SALICYLATE
}

\author{
BY
}

\author{
B. B. GAITONDÉ, S. N. JOGLEKAR AND S. V. SHALIGRAM
}

From the Department of Pharmacology and Therapeutics, Grant Medical College, Bombay, India

(Received March 6, 1967)

Salicylates have complex effects on carbohydrate metabolism. A rise or fall in blood glucose level follows the administration of salicylates depending upon the conditions of the experiment. Large doses may produce hyperglycaemia in normal animals, an effect held to be due to activation of the hypothalamic sympathetic centres and consequent adrenaline release (Goodman \& Gilman, 1965). Other mechanisms implicated in the response are: (a) an increased absorption of glucose from the gut, (b) a reduced aerobic metabolism of glucose, (c) an augmented glycogenolysis due to increased glucose-6phosphatase activity and (d) increased adrenocortical activity (Stowers, 1963).

A central site for the hyperglycaemic action of morphine has been proposed by Borison, Fishburn, Bhide \& McCarthy (1962) and for leptazol and, in certain circumstances, for adrenaline by Hasselblatt \& Sproull (1961). Salicylates are thought to act at the hypothalamic level to bring about antipyresis and central sites of action are presumably involved in the other responses to salicylates. It was, therefore, deemed of interest to seek a possible central site of the hyperglycaemic action of sodium salicylate.

\section{METHODS}

Animals and general procedures

Eighty-two cats of either sex weighing between 2 and $5 \mathrm{~kg}$ were used. To ensure an adequate carbohydrate intake, they were given a dietary supplement of glucose $(2.5 \mathrm{~g} /$ day $)$ for at least 3 days before the experiment. Pentobarbitone sodium $(40 \mathrm{mg} / \mathrm{kg})$ was injected intraperitoneally to induce anaesthesia, which was maintained by intravenous injection of small doses when required. The rectal temperature was maintained at $99^{\circ} \pm 1^{\circ} \mathrm{F}$. In the first few experiments, blood pressure and respiration were recorded. However, in the doses used, sodium salicylate did not produce marked changes in blood pressure and respiration.

\section{Routes of administration of sodium salicylate}

In acute experiments, intravenous injections were made into the femoral vein ; in recovery experiments, an indwelling catheter with a metal connector and a puncture cap was placed in the external jugular vein and secured by a harness.

The techniques for injection into the carotid and vertebral arteries were those described by Gaitondé, McCarthy \& Borison (1965).

Injection into the cerebral ventricles was through a cannula implanted in the lateral ventricle by the technique of Feldberg \& Sherwood (1954). After injection of the desired dose of sodium salicylate dissolved in $0.2 \mathrm{ml}$. of a $0.9 \% \mathrm{NaCl}$ solution, the lumen of the cannula was washed with 
$0.05 \mathrm{ml}$. of a $0.9 \% \mathrm{NaCl}$ solution. At the end of each experiment, $0.25 \mathrm{ml}$. of an aqueous suspension of indian ink was injected, followed by perfusion of the ventricles with a $10 \%$ formaldehyde solution; the indian ink was found to be distributed throughout the ventricular systems.

In 3 cats, $0.1 \mathrm{ml}$. of a solution of sodium salicylate $(100 \mathrm{mg} / \mathrm{ml}$.) was injected into the cisterna magna.

\section{Operative procedures}

In acute experiments on 7 cats, the spinal cord was transected at $T 2$. In recovery experiments on 2 cats this operation was performed under aseptic conditions. At the end of the operation, $25 \mathrm{ml}$. of a $5 \%$ glucose solution was injected through an indwelling catheter in the external jugular vein and a mixture of penicillin and streptomycin was injected intramuscularly.

In acute experiments on 4 cats the brain stem was transected in the mid-collicular plane. After bilateral removal of the cranium between the fronto-parietal suture and the occipital ridge the dura was incised and the brain stem exposed by gently pushing up the overhanging cerebral hemispheres. The brain stem was sectioned between the colliculi by a blunt, thin, narrow, plastic blade. The completeness of the section was verified after fixing the brain in a $10 \%$ formaldehyde solution.

Adrenalectomy was performed in acute experiments on 9 cats. The vessels issuing to and from the glands were ligated and the adrenals removed. In 5 cats a ventricular cannula was implanted. In 4 cats which served as controls a sham abdominal operation was performed and a lateral ventricular cannula implanted.

\section{Assessment of effects of administration of sodium salicylate on blood glucose}

The fasting blood glucose ranged in different animals from 70 to $110 \mathrm{mg} / 100 \mathrm{ml}$. blood. However, since the blood glucose of any one cat varied less than $10 \mathrm{mg} / 100 \mathrm{ml}$. blood during a period of $2 \mathrm{hr}$, a rise of at least $20 \mathrm{mg} / 100 \mathrm{ml}$. was deemed to be a hyperglycaemic response.

Sodium salicylate was administered by different routes after the blood glucose had stabilized. For estimation of blood glucose, blood samples were collected 10, 30, 60 and $120 \mathrm{~min}$ after the administration of sodium salicylate. When there was no response to sodium salicylate, adrenaline hydrochloride $(0.5 \mathrm{mg} / \mathrm{cat})$ was injected intramuscularly. Blood glucose was estimated by a modification of Somogyi's method (1952); sodium salicylate added to blood did not interfere with glucose estimation.

\section{RESULTS}

\section{Effects of intravenously injected sodium salicylate}

In a dose of $10 \mathrm{mg} /$ cat or, on the average, $3.8 \mathrm{mg} / \mathrm{kg}$ body wt., sodium salicylate had no effect on blood glucose (Table 1). With large doses, the number of animals responding

TABLE 1

\section{EFFECT OF INTRAVENOUSLY INJECTED SODIUM SALICYLATE ON BLOOD GLUCOSE OF}

Control blood glucose is the mean blood glucose level before administration of sodium salicylate. The mean maximal rise has been calculated from all the animals tested, whether or not they showed a hyperglycaemic response-that is, a rise of blood glucose of more than $20 \mathrm{mg} / 100 \mathrm{ml}$.

\begin{tabular}{|c|c|c|c|}
\hline Dose & $\begin{array}{c}\text { Control } \\
\text { blood glucose } \\
\text { (mg/100 ml. } \\
\pm \text { S.E.M.) }\end{array}$ & $\begin{array}{l}\text { No. of } \\
\text { animals showing } \\
\text { hyperglycaemia/ } \\
\text { total no. } \\
\text { tested }\end{array}$ & $\begin{array}{c}\text { Mean maximal } \\
\text { rise over } \\
\text { control } \\
\text { (mg/100 ml. } \\
\pm \text { S.E.M.) }\end{array}$ \\
\hline $\begin{array}{c}10 \mathrm{mg} / \mathrm{cat} \\
5 \mathrm{mg} / \mathrm{kg} \\
10 \mathrm{mg} / \mathbf{k g} \\
25 \mathrm{mg} / \mathrm{kg}\end{array}$ & $\begin{array}{l}88 \pm 4 \cdot 8 \\
85 \pm 3 \cdot 9 \\
92 \pm 6 \cdot 2 \\
82 \pm 4 \cdot 5\end{array}$ & $\begin{array}{l}0 / 5 \\
3 / 5 \\
5 / 6 \\
6 / 6\end{array}$ & $\begin{array}{l}22 \overline{ \pm 10 \cdot 8} \\
31 \pm 5 \cdot 8 \\
38 \pm 4 \cdot 2\end{array}$ \\
\hline
\end{tabular}


with hyperglycaemia increased with increasing doses but the magnitude of the response was not dose-dependent. Thus there was no significant difference between the maximal tise following 5 or $25 \mathrm{mg} / \mathrm{kg}$. A rise in blood glucose was not observed until $30 \mathrm{~min}$ or more after the administration of sodium salicylate, except in 1 cat which responded within $10 \mathrm{~min}$. The hyperglycaemia was at its peak 60 to $90 \mathrm{~min}$ after injection of sodium salicylate (Fig. 1).

The effect of spinal and mid-collicular brain section on the hyperglycaemia response to sodium salicylate

Acute or chronic transection of the spinal cord at T2 abolished the hyperglycaemic response to intravenous injection of sodium salicylate; indeed, in 3 cats with acute transection, blood glucose fell by $46 \pm 5.77 \mathrm{mg} / 100 \mathrm{ml}$. within 10 min after injection of sodium salicylate (Table 2). The hyperglycaemic response to adrenaline hydrochloride $(0.5 \mathrm{mg} / \mathrm{cat})$, too, was depressed in the spinal cats-viz., blood glucose rose by only $38 \pm 12.4 \mathrm{mg} / 100 \mathrm{ml}$., compared with $149 \pm 4.9 \mathrm{mg} / 100 \mathrm{ml}$. in the intact cats.

In all 4 cats with mid-collicular transection, sodium salicylate produced within $30 \mathrm{~min}$ a hyperglycaemic response which was not significantly different from that obtained in the intact cats $(P<0.1)$.

TABLE 2

THE EFFECT OF SPINAL OR MID-COLLICULAR TRANSECTION ON THE HYPERGLYCAEMIC RESPONSE TO INTRAVENOUS INJECTION OF SODIUM SALICYLATE

\begin{tabular}{|c|c|c|c|}
\hline $\begin{array}{c}\text { Dose } \\
\text { (mg/kg } \\
\text { body wt.) }\end{array}$ & $\begin{array}{l}\text { Control } \\
\text { blood glucose } \\
\text { (mg/100 ml. } \\
\pm \text { S.E.M.) }\end{array}$ & $\begin{array}{c}\text { No. of } \\
\text { animals showing } \\
\text { hyperglycaemia/ } \\
\text { total no. } \\
\text { tested }\end{array}$ & $\begin{array}{c}\text { Mean maximal } \\
\text { rise over } \\
\text { control } \\
\text { (mg/100 ml. } \\
\pm \text { S.E.M.) }\end{array}$ \\
\hline $\begin{array}{l}10^{*} \\
25^{*} \\
25 \dagger\end{array}$ & $\begin{array}{r}138 \pm 5 \cdot 7 \\
132 \pm 6 \cdot 5 \\
90 \pm 3 \cdot 8\end{array}$ & $\begin{array}{l}0 / 9 \\
0 / 4 \\
4 / 4\end{array}$ & $\overline{-}$ \\
\hline
\end{tabular}

* Pooled results obtained on 7 cats with acute transection and 2 cats with chronic transection of the spinal cord at T2. † Results obtained from 4 cats with transection of the brain stem at the mid-collicular plane.

TABLE 3

THE EFFECTS OF SODIUM SALICYLATE INJECTED INTO THE LATERAL VENTRICLE, THE CISTERNA MAGNA, THE CAROTID ARTERY OR THE VERTEBRAL ARTERY

\begin{tabular}{|c|c|c|c|}
\hline $\begin{array}{c}\text { Site of } \\
\text { administration } \\
\text { of sodium } \\
\text { salicylate } \\
(10 \mathrm{mg} / \text { cat })\end{array}$ & $\begin{array}{l}\text { Control } \\
\text { blood glucose } \\
\text { (mg/100 ml. } \\
\pm \text { S.E.M.) }\end{array}$ & $\begin{array}{c}\text { No. of } \\
\text { animals showing } \\
\text { hyperglycaemia/ } \\
\text { total no. } \\
\text { tested }\end{array}$ & $\begin{array}{c}\text { Mean maximal } \\
\text { rise over } \\
\text { control } \\
\text { (mg/100 ml. } \\
\pm \text { S.E.M.) }\end{array}$ \\
\hline $\begin{array}{l}\text { Ventricle } \\
\text { Cisterna magna } \\
\text { Carotid artery } \\
\text { Vertebral artery }\end{array}$ & $\begin{array}{l}114 \pm 5 \cdot 7 \\
103 \pm 2 \cdot 8 \\
100 \pm 2 \cdot 6 \\
102 \pm 1 \cdot 5\end{array}$ & $\begin{array}{l}5 / 6 \\
0 / 3 \\
1 / 3 \\
4 / 5\end{array}$ & $\begin{array}{l}48 \pm 10 \cdot 8 \\
= \\
48 \pm 12 \cdot 5\end{array}$ \\
\hline
\end{tabular}

The effects of sodium salicylate administered by different routes

Intraventricular administration and injection into the vertebral artery of $10 \mathrm{mg}$ sodium salicylate produced hyperglycaemia in 9 out of 11 cats, while injection into the cisterna magna or the carotid artery was ineffective, except in 1 cat (Table 3). Moreover, the 
rise in blood glucose occurred earlier and was larger when $10 \mathrm{mg}$ sodium salicylate/cat was injected into the ventricles or the vertebral artery than when $10 \mathrm{mg} / \mathrm{kg}$ body wt. was given intravenously (Fig. 1). Thus, in 3 out of 5 cats given sodium salicylate by the ventricular route, and in 3 out of 4 cats given it by injection into the vertebral artery, the hyperglycaemic response was present within $10 \mathrm{~min}$, while in the remaining cats the response was seen within $30 \mathrm{~min}$.

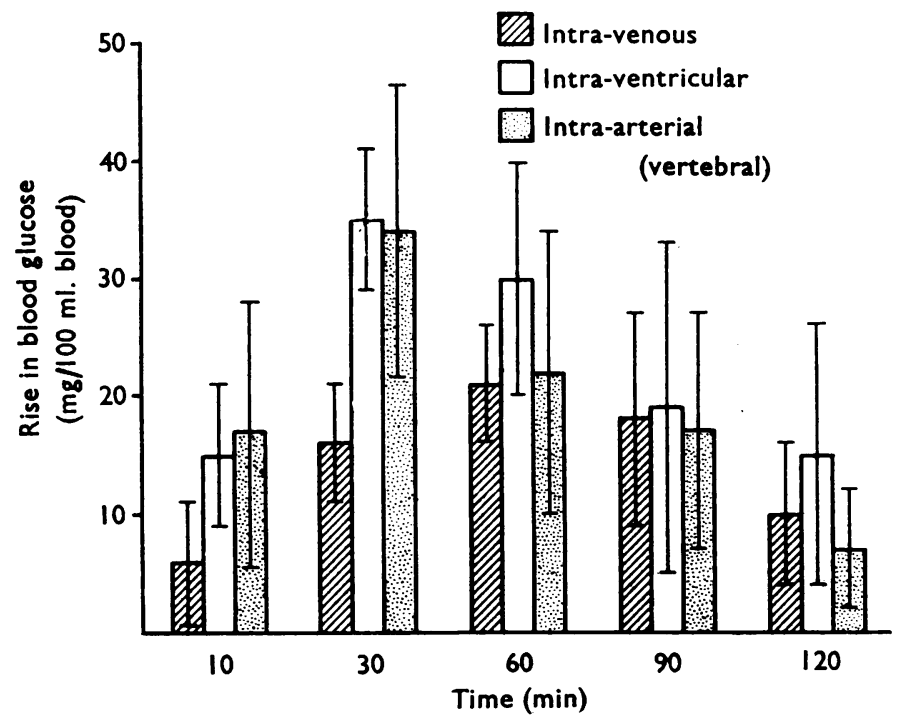

Fig. 1. The time course of the hyperglycaemic response to administration of sodium salicylate by different routes: shaded column, femoral vein $(10 \mathrm{mg} / \mathrm{kg})$; clear column, lateral ventricle $(10 \mathrm{mg} / \mathrm{cat})$; dotted column, vertebral artery $(10 \mathrm{mg} / \mathrm{cat})$. The vertical lines represent standard errors of the means.

\section{Effect of sodium salicylate on blood glucose in adrenalectomized cats}

Adrenalectomy reduced the hyperglycaemic response to intravenous injection of sodium salicylate and abolished the response to intraventricular administration of the drug (Table 4), although injection of adrenaline hydrochloride $(0.5 \mathrm{mg} /$ cat) could still raise the blood glucose of the adrenalectomized cats by $102 \pm 3.8 \mathrm{mg} / 100 \mathrm{ml}$. blood.

TABLE 4

EFFECT OF SODIUM SALICYLATE, ADMINISTERED INTRAVENOUSLY OR INTO THE LATERAL VENTRICLE, ON THE BLOOD GLUCOSE OF ADRENALECTOMIZED CATS

$\begin{array}{cccc}\begin{array}{c}\text { Route of } \\ \text { administration } \\ \text { and dose }\end{array} & \begin{array}{c}\text { Control } \\ \text { blood glucose } \\ (\mathrm{mg} / 100 \mathrm{ml} \\ \pm \text { S.E.M.) }\end{array} & \begin{array}{c}\text { No. of } \\ \text { animals showing } \\ \text { hyperglycaemia/ } \\ \text { total no. } \\ \text { tested }\end{array} & \begin{array}{c}\text { Mean maximal } \\ \text { rise over } \\ \text { control } \\ \text { (mg/100 ml. } \\ \pm \text { S.E.M.) }\end{array} \\ \begin{array}{c}\text { Intravenous } \\ 10 \mathrm{mg} / \mathbf{k g}\end{array} & \begin{array}{c}90 \pm 6 \cdot 4 \\ 90 \pm 6 \cdot 8\end{array} & 1 / 3 & 15 \\ 25 \mathrm{mg} / \mathrm{kg} & 4 / 6 & 29 \pm 8 \cdot 7 \\ \begin{array}{c}\text { Intraventricular } \\ 10 \mathrm{mg} / \text { cat }\end{array} & 85 \pm 4 \cdot 6 & 0 / 5 & -\end{array}$




\section{DISCUSSION}

In the dose range of sodium salicylate used by us, there appears to be a quantal relationship between the dose and the number of animals responding with hyperglycaemia. The magnitude of the response and its time course, however, do not appear to be dosedependent.

There is considerable evidence for the view that the hyperglycaemia is due to an action of sodium salicylate on structures in the brain. In cats with acute or chronic transection of the spinal cord, the hyperglycaemic response is absent; moreover, a marked hyperglycaemia is induced by injection into the lateral ventricle or vertebral artery of a dose of sodium salicylate which is ineffective when injected into the femoral vein.

As the magnitude of the response is not related to the dose of sodium salicylate, it is not possible to establish a ratio of equiactive doses given by the intravenous, intraventricular or intra-arterial routes. However, since sodium salicylate is equally effective whether injected into the ventricles or the vertebral artery, the receptors for this drug are probably located in deeper rather than superficial layers around the cerebral ventricles. Morphine seems to be different in this respect, since it is 50 times more potent when given by intraventricular than by intravenous injection (Borison et al., 1962).

In this connection it is of interest that, in conscious cats, intraventricular injection of $0.5 \mathrm{mg}$ sodium salicylate fails to produce emesis (unpublished observation). Bhargava, Chandra \& Varma (1963) postulate that in dogs the chemoreceptor trigger zone is the site for the emetic effect of intravenously injected sodium salicylate. The emetic action of digitalis can be readily evoked by injection into the vertebral artery, but not by injection into the ventricles (Gaitondé et al., 1965).

Feldberg (1963) showed that the effects of drugs differ depending upon whether they are applied from inside or outside the blood-brain barrier. In our experiments, intracisternal administration of sodium salicylate did not evoke hyperglycaemia. A drug administered in this way would tend to travel towards the tuber cinereum, an area held by Feldberg (1963) to be responsible for the hyperglycaemia caused by adrenaline. However, sodium salicylate does not appear to activate this area.

The hyperglycaemic response is well preserved in cats with transection of the brain stem in the mid-collicular plane and is possibly even exaggerated, an observation indicating that the central site is caudal to the hypothalamus. Other workers have localized the sites of some of the actions of salicylates at both supra- and infra-collicular levels. For instance, the antipyretic action of aspirin is absent in monkeys with hypothalamic lesions (Guerra \& Brobeck, 1944). On the other hand, direct application of salicylate to the medulla results in hyperventilation (Tenney \& Miller 1955); this effect may be due to an action on the medullary respiratory integrator site (Rosenstein \& Borison, 1963) or on a site in the infracollicular region (Pentiah, Reilly \& Borison, 1966).

Other drugs causing hyperglycaemia may have their site of action caudal to the hypothalamus ; for instance, Hasselblatt \& Sproull (1961) suggested that adrenaline may act in the region of the floor of the fourth ventricle. However, Borison et al. (1962) observed that destruction of the area postrema does not interfere with the hyperglycaemic effect of adrenaline. 
The hyperglycaemic response to intraventricular injection of sodium salicylate is dependent on the release of catecholamines from the adrenal medulla, since the effect is absent in adrenalectomized cats. The explanation of the residual hyperglycaemic response observed after intravenous injection of sodium salicylate in adrenalectomized cats may be that it is due either to aberrant adrenals or to efferent pathways which, when activated, produce hyperglycaemia without the release of catecholamines from the adrenal medulla.

As the hyperglycaemic response to intravenous injection of sodium salicylate is not abolished by mid-brain transection, an integrator site below the mid-collicular plane may be responsible for the release of catecholamines from the adrenal medulla.

\section{SUMMARY}

1. The object of the present work was to localize the site of the hyperglycaemic action of sodium salicylate.

2. Sodium salicylate, in doses ranging from 5 to $25 \mathrm{mg} / \mathrm{kg}$, was administered intravenously to intact anaesthetized cats in order to study the relationship between the dose and the hyperglycaemic response.

3. In cats with acute or chronic transection of the spinal cord, sodium salicylate failed to evoke hyperglycaemia. Mid-collicular transection of the brain stem, however, did not abolish the hyperglycaemic response to sodium salicylate.

4. A dose of sodium salicylate $(10 \mathrm{mg} / \mathrm{cat})$, which was ineffective when injected into the femoral vein, the carotid artery or the cisterna magna, caused marked hyperglycaemia when injected into the vertebral artery or the lateral cerebral ventricles. This indicated a site of action in the part of the brain supplied by the vertebral artery.

5. Adrenalectomy reduced the hyperglycaemic response when sodium salicylate was injected intravenously and abolished it after intraventricular administration.

6. It is considered that sodium salicylate acts on a site or sites below the midcollicular plane of the brain stem.

\section{REFERENCES}

Bhargava, K. P., Chandra, O. M. \& Varma, D. R. (1963). The mechanism of the emetic action of sodium salicylate. Br. J. Pharmac. Chemother., 21, 45-50.

Borison, H. L., Fishburn, B. R., Bhide, N. K. \& McCarthy, L. E. (1962). Morphine induced hyperglycemia in the cat. J. Pharmac. exp. Ther., 138, 229-235.

FELDBERG, W. (1963). A Pharmacological Approach to the Brain from its Inner and Outer Surfaces. Edward Arnold, London.

FeldBerg, W. \& SHERwood, S. L. (1954). Injections of drugs into the lateral ventricle of the cat. $J$. Physiol., 123, 148-167.

GatTondé, B. B., MCCARTHY, L. E. \& Borison, H. L. (1965). Central emetic action and toxic effects of digitalis in cats. J. Pharmac. exp. Ther., 147, 409-415.

Goodman, L. S. \& Gilman, A. (1965). The Pharmacological Basis of Therapeutics, 3rd Ed., p. 322. Macmillan, New York.

GUERRA, F. \& BROBECK, J. R. (1944). The hypothalamic control of aspirin antipyresis in the monkey. J. Pharmac. exp. Ther., 80, 209-216.

Hasselblatt, A. \& Sproull, D. H. (1961). Hyperglycaemia induced by drugs. J. Physiol., 157, 124-136. 
Pentiah, P., Reilly, F. \& Borison, H. L. (1966). Interactions of morphine sulfate and sodium salicylate on respiration in cats. J. Pharmac. exp. Ther., 154, 110-118.

Rosenstein, R. \& Borison, H. L. (1963). Actions of carbon dioxide and sodium salicylate on central control of respiration in cats. J. Pharmac. exp. Ther., 139, 361-367.

Somogyi, M. (1952). Notes on sugar determination. J. biol. Chem., 195, 19-23.

STOWERS, J. M. (1963). Salicylate and clinical diabetes and remarks on other endocrine effects. In Salicylates, p. 67. Ed. Dixon, A. St., Martin, B. K., Smith, M. J. H. \& Wood, P. H. N. Churchill, London.

TENNEY, S. M. \& MILLER, R. M. (1955). The respiratory and circulatory actions of salicylate. Am. J. Med., 19, 498-508. 